\title{
ONTOLOGICAL CONSEQUENCES OF THE ETHICS OF TECHNOLOGY
}

\begin{abstract}
Development of new technologies is accompanied by a necessary ethical reflection of them. This ethical reflection, for the sake of the legitimization of its own discourse, defines the relations between the fundamental ontological categories such as human, culture, nature, technology and product. Ontological interpretation of these relations is bound to the specific model of rationality. This study compares two types of rationality for the interpretation of the relations between the concepts of man, nature, and the culture of technological developments and formulates the ontological consequences of both approaches. The first approach is the theory of Arne Naes, who in his theory departs from an anthropocentric starting point for understanding the relation between man and nature, preferring instead an understanding of the biosphere as a bearer of moral values [1]. The bearer of values is not in the human consciousness which makes the evaluation of objects and nature but the bearer is in the ecosystem and its autonomous existence. Bruno Latour, on the contrary, includes in the complexity of being not only human beings but also the products of technological processes, calling them hybrids or quasi-objects. The nature and quasi-object together constitute a sphere of transcendence. A comparison of the two approaches is focused on the definition of transcendence as a potential bearer of values, meanings and moral responsibility. We compare both approaches and evaluate the possibility of their use in the development of new concepts in ethics of technology.
\end{abstract}

Keywords: Ontology, ethics, technology, transcendence, responsibility.

\section{Introduction}

The aim of this paper is to examine the relationship between moral decision making of the human subject and the ontological model that one applies to (or rather, imposes on) reality. We wish to critically observe which objects we consider as bearers of moral value and how we verify their capacity to be such bearers. Before going to ontological consequences, we must first clarify the relation between ontology and ethics in the context of its application in the area of technologies. Ethics offers several approaches to understanding good and its interpretation. Due to different ways of understanding good, various ethics offer differing explanations of why humans do good and why they avoid evil. Our choices differ in spite of the fact that their common denominator is a pursuit of good. This is true, above all, in applied ethics. Human life as a value stands in the center of our efforts. This value, however, expresses itself differently in medical professions, in nursing, police, or in a school setting. The commonly used differentiation between general and applied ethics is fully valid here: general ethics talks about good in the sense of an autonomous object and applied ethics refers to it in terms of concrete ways of searching the good on various levels of human practice. The task of general ethics is to find a legitimizing framework in which we may justify and explain what is good and evil. In applied ethics, then, we apply this legitimizing framework into practice and determine which concrete actions are good and which are not.

Nevertheless, we are confronted with the following question: Are we able to find a common consensus in general ethics, that is, a consensus acceptable by all as an ideal of good, which we could then apply in practice? This is the desire, the wish that originated in the Enlightenment, which sought to replace the legally constitutive, universally valid and accepted role of God with the new authority of reason. Indeed, "the underlying characteristic of Enlightenment is an uncritical faith in the objectivity of human reason - in the capacity of reason (a metaphysical, transpersonal category) to explain the world and to teach the human race how to live in it" [2, p. 197]. This new authority was to have the same attributes as God. Reason, thus, was supposed to postulate universally valid rules that would be respected by all. Along

\footnotetext{
* 1Peter Kondrla, ${ }^{2}$ Primoz Repar

${ }^{1}$ Department of Religious Studies, Faculty of Arts, Constantine the Philosopher University in Nitra, Slovakia

${ }^{2}$ Central European Research Institute of Soren Kierkegaard. Ljubljana, Slovenia

E-mail: pkondrla@ukf.sk
} 
with Palitefka we may ask whether our contemporary Western civilization, driven by such ambitions, has any future at all [3, p. 33].

\section{The question of Relativity and Plurality}

The vision of modernity, originating from the Enlightenment, was a unity. This concept arises out of a conviction that there is but one universally valid truth that people across cultures and religions are able to understand and accept. For the enlightened reason, only that which can be proven, verified and ultimately proven as useful for man can be accepted as truth. This usefulness, however, ended up being reduced to an economic dimension. To prove the existence of good within the legitimizing processes of the Enlightenment was impossible. On the other hand, to measure usefulness through gain was and has remained possible, as we can witness in our everyday experience.

From its very conception, modernity has been confronted by plurality. It was held unacceptable for there to exist a different opinion which would vary from the commonly accepted one and yet be true. One common truth and one common good was the ideal of the age. The fulfillment of the ideal of truth in modernity, however, came into conflict with the freedom of the human. Freedom spawns a plurality of stances, attitudes and opinions, thereby calling into question the supposed unity of truth. This approach, in addition, often produces despair for which science has been unable to provide a solution, as Pavlíková points out [4, p. 193]. A number of authors concur that reason produced by the Enlightenment had become the cause of the biggest catastrophes of the past century. People murdered other people in the name of truth; countless victims were deprived of the freedom of thinking, expression and action.

Against the background of this historic experience, we are confronted today with an opposite extreme, the view that everything is permissible and justifiable. This phenomenon is generally linked with postmodernity. Moral choice becomes irrelevant here. There are no rules that should be followed, no authority which holds us responsible. Both of these extremes have much in common, actually, but there is one essential difference that rests in their ontological concept of reality.

The Enlightenment's concept of being results in the vision of reason as consciousness, as the only authentic being, as Heidegger (among others) was known to claim. His concept of dasein concentrated into the consciousness of the individual is further softened by other authors, such as Lévinas, dialogical philosophy, the so-called search for the face of the other, and the search for meaning of one's own existence in relation with the other Thou. Levinas' correction is the expression of being appalled by the fact how a human can look into the eyes of another human being, a suffering, tortured human - and still consider it good. The very sight of the suffering eyes should stir the inner self of the human.
For the modernity, such sight is not problematic because the other still remains a mere object, as Debnar points out [5, p. 769]. It can be so, because the Enlightenment's reason transcends all being, for it is the steward of the world and lawgiver. The whole reality is shifted to the pole of immanence. Postmodernity, on the other hand, shifts the whole reality to the pole of transcendence. Reason is not able to understand, it is not able to know and do good, hence it loses all its competences and authority. Both solutions are radical and neither of them is practically viable. The functioning of the first scenario, i.e. when reason transcends all of reality, as we have already indicated, leads to a totality by precluding free decision making and action. In the second scenario, the human individual becomes a toy in the hands of the reality - a reality which one does not understand, which one fears and where one fails to find a meaning of one's existence.

The fundamental question that arises in connection with the application of general moral categories in the concrete dimensions of practical life thus remains unchanged: Who is the bearer of moral value? To define the status of the bearer of moral value is decisively important because in order for us to be able to determine who is responsible of any given action and to whom one is responsible. We may perceive this responsibility from two perspectives. The first one revolves around one's responsibility to someone, i.e. an authority which sets the norms. The second perspective focuses on the object of responsibility, that is, who or what are we responsible for. To be accountable to someone means to accept his (her) authority as a norm-giver and to respect his model of differentiation between good and evil. In the case of religious ethics, God is this norm-giver, guaranteeing by his transcendence the correct differentiation between good and evil. However, as we pointed out before, reason, too, strives to transcend reality and offer definite solutions to the question of what is good and what is evil. A peculiar dialectic relationship of reason to itself emerges here. Reason is the norm-giver, while simultaneously being the one who subordinates itself to the norm. Transcendence thus overlaps with immanence.

\section{Between Reason and Irrationality}

The rise and fall of reason from the time of the Enlightenment to the present has been accompanied by attempts at a correction and a new definition of the significance and the role of reason. Especially in the $19^{\text {th }}$ century, several philosophical schools emerge which try to reduce the significance of rationality at the expense of "irrationally" defined principles of being. Voluntarism or the philosophy of values might be mentioned as good examples. Volition dominates the former one, while a discerning feeling rules the latter one. Both stand in a radical opposition to rational principles of formal logic and the economics that is often associated with it. That, which brings profit, is logically good and that, which brings loss, is evil. Helping one's neighbor, taking care 
of the sick, self-sacrifice - all of these are actions that produce loss. The weak has to die to allow the strong to grow. That, which is weaker, is colonized and subjected to the stronger (i.e. reason), being obliged to serve and obey its dictate [6].

The Danish existentialist, Soren Kierkegaard, belonged among the most vocal critics of this paradigm. His criticism targeted the simplified logic of formalism, namely the formalism in ethics and in religious faith. As Kralik and Torok point out, the human individual is constantly being tossed back and forth in one's restless search for new experiences, plunging into the stream of mass society where one loses one's subjectivity [7, p. 67]. Kierkegaard brings to our attention an interesting, paradoxical consequence of applying reason as it is defined by the Enlightenment. He talks about the mortification of live faith that originally consisted of an immediate, live relationship of the human individual with God. The critique of formalism is closely related to the critique of large, rationalistic conceptions, including the Hegelian system of the Absolute Spirit. It is precisely this model of thinking which so clearly represents the absolute rule of rationality, from which there is no escape. Even freedom subordinates itself to reason and law. This approach subordinates human individuals to the dictate of the society, in Hegel's case to the dictate of the state. Kierkegaard draws a parallel to the case of religion. Formalism binds the believer into a system, subjecting one to the rules and commands of the system, while failing to provide meaning to his unique existence. In the words of Kralik and Torok, priests do not proclaim God's truth but rather their own truth [8, p. 50].

Kierkegaard sees the individual as a maker of the meaning of his own existence, whereby the human is connected to the source which leads one through despair and often also acute suffering to an understanding of one's own existence. Even though Kierkegaard does not aspire to become a critic of science or that of an applied ethicist, he offers a way, as seen from the perspective of ontology, which is essentially different from the way that had been set before him by Hegel and those following his methodology. The relationship between a subject and an object is highly problematic for Kierkegaard. It limits human individuals in their possibilities of immediate search for the meaning of their own existence. This relationship between a subject and an object, at the same time, indicates an asymmetric position in which the subject observes and determines rules, whereas the object is subjected to observation, categorization, and manipulation. Kierkegaard points out that the relationship of subject and object brought to the front the question of truth that had become the source of power, rule over and control of the objects. At the same time, the categories of good and evil slowly disappear from the focus of the intellectuals. Morality steps back into the background and leaves space for gnoseology. Gnoseology, however, is not a path for searching the truth that would set humans free. Instead, it is a search for truth which might place another human individual in the position of an object and enslave him.
This is precisely what has become a source of problems for the modern thinking and the application of reason as a tool of knowledge that transcends over the reality and which decides its fate. If humans, on account of their being smarter (i.e., more reasonable), claim transcendence over nature and other living things, then this notion of transcendence will lead them to an ecological crisis that we witness today. If one, in the name of any truth, claims transcendence over other people, then resulting from such notion of transcendence are human catastrophes, world wars, conflicts, refuges etc. There is an absence, in both cases, of responsibility, not only on the individual level but also on the social level, as Jurová argues in her recent study [9, p. 71]. What Kierkegaard indicated already in the $19^{\text {th }}$ century, came to the forefront of philosophical and ethical discourses of the $20^{\text {th }}$ century. Their solutions usually revolved around trying to redefine the 'subject - object' relationship, as well as around a new understanding of what we consider to be reality [10].

\section{The new ontology of 'Deep Ecology'}

In addition to the failures of the supposedly 'naked rationality' of modernity, we have presented a summary of an astute criticism from the side of postmodernity, pointing out that reason did not manage to prevent catastrophes from happening. Instead, reason posited itself into the position of a ruler over life and what it means to be human. Not only reality but also human dignity became immanent. It became an object of interpretations from the position of rationality.

This is where a key question arises, the question of relationship between subject and object. To what extent may we leave an open space for interpretation and can be interpreted and defined by reason? Applied ethics in relation to new technologies is always confronted with the question: on what basis can we determine the limits of reason? On one hand, we have given up on the ability of reason to create a meaning of being; on the other hand, thanks to new technologies, we have reached deep inside some of the most mysterious realms of human life. Crucial in this context seems to be the question: 'who is the bearer of moral value?'. Is it the human being? If so, then we need to ask, who is a human being, when does one's life begin and when could it be said that one's life has ended? Can we, at least in a certain sense, speak of animals as bearers of moral value? Better yet, do the machines and the products of our intelligence and wisdom belong to the sphere of moral value bearers? Answers to these questions are closely linked to our particular ontological perspective.

We wish to present the holistic concept propounded by A. Naess. In his concept, Naess places the ontological dimension of the bearer of moral value on all living things, with which we co-create together a living organism and in which all of us share a mutual responsibility for the state of the living environment and the planet. Also resulting from this organic reality, is our 
responsibility to take care of our environment. Due to our abilities and possibilities, we find ourselves in a position where we must not do otherwise but to assume this responsibility. Jurová, in this connection, points out the model of the so-called tolerant society, where subjectivity is transferred from the individual to a society that is open to dialogue and that is able, in this dialogical environment, to search for solutions to its problems [11, p. 144] Such tolerance, however, is yet again based on rationality.

A new movement of the so-called 'deep ecology' develops within the environmental ethics in connection with Naess' emphases, perceiving humans as integral part of nature (and vice versa). From the viewpoint of ontology, such approach is in contrast to the modern 'subject-object' dichotomy. Such relation between subject and object constitutes an imbalance in nature because the object becomes a mere 'object of scrutiny', subject to manipulation. The subject, on the other hand, rules and decides about the value attributed to the given object, as well as how the object would be utilized in the system. The 'deep ecology' approach responds to the ensuing abuses that are engendered by this system. In addition, our current ecological situation is a stark reminder of the inadequacy of the old, dichotomist thinking. Instead of its nurturing function, our living environment confronts us with acute threats. According to deep ecology, nature has its own intrinsic value, which cannot be derived from its usefulness to humans. The critique of anthropocentrism from the side of postmodernity is in line with the critique propounded by deep ecology. The artificial dualisms between subject and object, culture and nature, reason and non-consciousness (etc.) has proved itself to be untenable. The rational, self-aware subject loses its ability to transcend reality. Deep ecology, contrary to that, draws the isolated subject into a holistic being. The process of returning the human individual as a subject into the complexity of being happens by means of forsaking the rationalistic, dictatorial positions, assuming instead irrational positions, in the context of which, due to empathy, we are finally able to identify with nature and the planet (perceived as a holistic being) as its integral part. We see a similar line of argument in Antošová who comes up with the notion of a 'transcendent concept of love' [12, p. 137]. Human being is not the measure of all things, quite on the contrary, the value of humans is measured by their presence in all things.

From the perspective of the interpretation of being, the human is unique only in the sense that one is able to become aware of one's moral responsibility for the whole. This realization, however, is not strictly rational; it is not a realization in terms of a rational calculation that if we continue to devastate nature, destroyed environment will become a threat to our own existence. This awareness is rather our empathizing with nature, while realizing our own partaking in a complex organism, in being itself, in Naess' sense.

In practical life, this kind of thinking has inspired countless activities of nature protection, though its application in the ethics of research remains complicated due to the ontological consequences that we pointed out before.

\section{The Metaphysics of Networks}

Latour, similar to Naess, strives to include a wider array of being in his concept of reality (besides the self-aware human being). In his concept of post-structuralist motivated theory of network agents, however, Latour surpasses the boundaries of biosphere. We may accept, along with Gogora, the term oligoptikon, which relatively accurately captures this shift [13, p. 489]. Latour searches for a solution that remained hidden from the modernity or, we should better say, he is trying to bring modernity to its real goal for, according to Latour, we have never been modern. However, he rejects being identified as a postmodern thinker, suggesting instead the term 'amodernity', which better encapsulates his ontological stance. Latour carefully examines the methodology and art in which modern science develops, arguing that scientist actually do not describe reality but rather construct a cosmological model the task of which is to verify all further evidence and claims. This, obviously, leads to separating human society from nature. Science goes even as far as to decide about truth and untruth in the process of knowing nature, as Latour's example pertaining to vacuum clearly shows.

Latour thus defines a new starting point that accepts two kinds of transcendence. The first one is the transcendence of nature and the second one is the transcendence of society. Contrary to previous claims, we encounter new types of transcendence here. The dualism of two transcendences, however, will incessantly engender a conflict and tension. Hence we will actually never move beyond the limits of modernity the paradigm of which we wished to forsake. Latour strives to remove the contradiction and conflict by means of a combination of both types of transcendence, using the process of redefining and re-purifying the so-called 'quasi-objects'. The purification of quasi-objects is a method that will enable us to comprehend the fact that just as society produces culture and objects, so also nature limits society and its possibilities of existence. It is not possible to find a univocal, conclusive answer to the question: 'what is on the side of the object and what is on the side of the subject?'. Therefore, he talks about 'quasi-objects' that are in a certain sense objects, while in another sense also subjects [14].

This ontological shift ultimately means that if we want to understand the moral dimension of our actions and the corresponding moral applications in science, we must neither assess them from an extreme, one-sided position of the creators of technologies, nor from the opposite extreme position of those who are threatened by these technologies. In this case, the ontological shift means that we must accept not only all living things but also all technical objects that we have created into the complexity of our responsibility. After all, we are already 
beginning to encounter the question of intelligent machines that are relatively autonomous in making choices, which raises the question of assuming responsibility for their decision making.

\section{Conclusion}

Our striving to solve the questions that originated as a result of technological advancement but also due to the intentional application of a dominant position of the Enlightenment's reason requires a change in our ontological interpretation of reality. The bipolarity of the world that has been an integral part of the foundations of our civilizational paradigm separates reality into subjects and objects, true and untrue, real and non-real. We have shown that our ontological position (view) should move to the middle, which ultimately means that we should forsake the superior position of the knowing subject and leave some space for doubt, including the possibility that we might actually be wrong. As Valco and Valcova point out, "The neglect of the subject and his inner world results in ambitious projects of human ideologies at the expense of the individual. The proud pursuit of objectivity without a recognition of human limitations, and the dimension of subjectivity in the process, has proved to be a dead end that emits the stench of manipulation, loss of human dignity, and finally nihilism" [15, p. 26]. We should rather embrace that the human does not intrinsically surpass reality through one's individuality or subjectivity, but is rather a member of an ontologically higher whole, i.e. the society or biosphere. Hence, an adequate point of departure (for Latour as well as for Naess) appears to be the forsaking of egoism that was originally constituted by the Enlightenment's subject. Although the shift from the position of 'I' to the position of 'we' is, in Latour, determined by his sociological approach, it brings similar results to those stemming from Naess' concept.

At the same time, we need to be aware of the danger that Kierkegaard warns about. Both, the holistic as well as the structuralist approaches significantly complicate one's personal relationship with God or, more generally, to transcendence, which is the basis for the individual' authentic experience of one's existence. In both cases, existence is either evaluated based on its participation in society, as defined by its position in the structure of the given society, or it is interpreted as a partial member of an organism, as an organ that functions in the context of biosphere as a whole. In both cases, thus, the situation amounts to a rejection of the ancient and Christian traditions which understood the human as a rational living entity whose essence was constituted by the unity of its body and soul. Human rationality meant, among other things, that humans were able to distinguish between good and evil and to make choices for the benefit of the good.

In the Enlightenment, however, rationality assumed a new dimension (to the detriment of the social and living environments). After its historic failure in the wars and concentration camps of the $20^{\text {th }}$ century, the only viable solution seemed to be to give up on the subject (as an individual) and to transfer the agency of the bearer of moral value onto the society, onto a collective consciousness, or a structure of objects and events that constitute moral meaning and value. After all, as Valco, Kralik and Barrett argue in their recent study, morality and values are an integral part of human society - they are "socially embodied, not individually based" [16, p. 104]. It remains to be seen, however, whether the set of possible solutions might also include a return to the original ideal of a virtuous, rational living being, with the conviction that "central to living a happy life is being a good, moral person" [17, p. 98]. This return would, in any case, require a personal, inner conversion, instead of legalism. It would require an intentional, personal stance, perhaps even the inner disposition of a hero, not the cowardly transfer of responsibility onto the society or our life circumstances. This question concerns science and the implementation of ethics in science. As long as a scientist functions only by the rules, often even violating them, this is a legalistic approach which indicates that the scientist is not that rational living being who distinguishes between good and evil. $\mathrm{He}$ is rather a scholar of the Enlightenment type, aspiring at all costs to increase the limits of knowledge and to penetrate deeper into the essence of things, cells, objects with the desire to rule over them (i.e., use them to one's own benefit). Nevertheless, the principle stays valid: he who wishes to govern others, must first manage to rule (control) himself. A good initial step might be, if general and applied ethics were not perceived as a useless waste of academic credits in educating future scientists but rather as a legitimate part of the development of personality of the future scientist. This might set us on the path of searching "for elements that might be utilized in building up a synthetic philosophical outlook on the reality of this world - an outlook that would not only map this reality but would also designate in it the necessary reference points adequate for human conduct and interaction" [18, p. 209].

\section{References}

[1] NAES, A.: Ecology, Community and Lifestyle: Outline of an Ecosophy. Cambridge University Press, 1993, p. 187. ISBN 9780521348737. 
[2] VALCO, M.: Alternative Viewpoint: Edwards and the World Religions. In G. McDermott (ed.), Understanding Jonathan Edwards, An Introduction to America's Theologian. Oxford, Oxford Univ. Press, 2009, 195-200.

[3] PALITEFKA, J.: The Future of Western Civilization in the Context of Oswald Spengler's Work. European J. of Science and Theology, vol. 12, No. 3, 2016, 33-43. ISSN 1841-0464. For more about the relationship between science and theology, see: HANES, P. \& MASARIK, M.: Complementarity of Science and Theology. European J. of Science and Theology, vol. 12, No. 6, 2016, 5-20. ISSN 1841-0464.

[4] PAVLIKOVA, M.: Despair and Alienation of Modern Man in Society. European J. of Science and the Theology, vol. 11, No. 3, 2015, 191-200. ISSN 1841-0464.

[5] DEBNAR, M.: Subjectivity in Writing from Ferdinand de Saussure to Paul de Man. vol. 1, Sofia: SGEM, 2016, 769-775. ISBN 978619-7105-52-0; also see: DEBNAR, M.: The Disappearance of the Author and Meaning Making (in Slovak), World Literature Studies, vol. 25, No. 3, 2016, 104-121. ISSN 1337-9690.

[6] As an anti-dote against this radical claim on truth, Diatka and Ligus propose a positively oriented skepticism that is not destructive but constructive. See: DIATKA, C., LIGUS, J.: Thinking about Certainty and tolerance with Michel Eyquem de Montaigne. Communications - Scientific Letters of the University of Zilina, vol. 18, No. 4, 2016, pp. 123-128. ISSN 1335-4205.

[7] KRALIK, R., TOROK, L.: Concept of Relationship God-Man in Kierkegaard's Writing 'What We Learn from the Lilies in the Field and from the Birds in the Air'. European J. of Science and Theology, vol. 12, No. 2, 2016, 65-74. ISSN 1841-0464.

[8] KRALIK, R., TOROK, L.: The Moment' Kierkegaard's Attack upon Christendom. European Journal of Science and Theology, vol. 12, No. 3, 2016, 45-53. ISSN 1841-0464.

[9] JUROVA, J.: On Etzioni's Concept of a Responsive Community. European J. of Science and Theology, vol. 12, No. 3, 2016, 71-80. ISSN 1841-0464.

[10] PAVLIKOVA, M.: The Concept of Anxiety and its Reflection in Auden's Work 'The Age of Anxiety'. European J. of Science and Theology, vol. 12, No. 4, 2016, 111-119. ISSN 1841-0464.

[11] JUROVA, J.: Ethical Aspects of Toleration from Liberal Perspective. European J. of Science and Theology, vol. 12, No. 1, 2016, 139-145. ISSN 1841-0464.

[12] ANTOSOVA, M.: Axiological Scope of Dominik Tatarka's Texts (Philosophy of Love) European J. of Science and Theology, vol. 12, No. 1, 2016, 129-137. ISSN 1841-0464.

[13] GOGORA, A.: Latour a Sartre v Cafe de Flore (Latour and Sartre in Cafe de Flore). Filozofia, vol. 67, No. 6, 2012,485 - 490. ISSN 0046-385 X.

[14] LATOUR, B.: We Have Never Been Modern. Harvard University Press, 1993. ISBN 0-674-94839-4.

[15] VALCO, M., VALCOVA, K.: Communications - Scientific Letters of the University of Zillion, vol. 16, No. 3, 2014, 25-28. ISSN 13354205.

[16] VALCO, M., KRALIK, R., BARRET, L.: Moral Implications of Augustine's Philosophical and Spiritual Journey in His Confessions. Communications - Scientific Letters of the University of Zillion, vol. 17, No. 2, 2015, 103-108. ISSN 1335-4205.

[17] VAlCOVA, K., PAVLIKOVA, M., ROUBALOVA, M.: Religious Existentialism as a Countermeasure to Moralistic Therapeutic Deism. Communications - Scientific Letters of the University of Zilina, vol. 18, No. 3, 2016, 98-104. ISSN 1335-4205.

[18] HAJKO, D.: Wilmon Henry Sheldon and his “Synthesis of Philosophies” (in Slovak), Filozofia, vol. 71, No. 3, 2016, 209-219. ISSN 0046-385 X. 